\title{
Hypothalamic Microinflammation: New Paradigm In Obesity And Metabolic Disease
}

\author{
Anna Meiliana ${ }^{1,2,}$, Nurrani Mustika Dewi², Andi Wijaya ${ }^{1,2}$ \\ ${ }^{1}$ Postgraduate Program in Clinical Pharmacy, Padjadjaran University, Jl. Eijkman No.38, Bandung, Indonesia \\ ${ }^{2}$ Prodia Clinical Laboratory, Jl. Cisangkuy No.2, Bandung, Indonesia \\ *Corresponding author. E-mail: anna.meiliana@prodia.co.id
}

Received date: Apr 17, 2020; Revised date: Jun 29, 2020; Accepted date: Jul 17, 2020

\section{Abstract}

$\mathrm{B}$ ACKGROUND: Hypothalamus is the master regulator of body's systemic homeostasis including energy balance, body temperature, sleep, blood pressure, and circadian rhythms. This review article will highlight the shifting of the old paradigm of obesityinflammation-metabolic syndrome, which was focused on visceral organs and systemic inflammation, into a new model involving microinflammation in the master regulator of endocrine system, i.e., hypothalamus.

CONTENT: Since the early stage of over-nutritional conditions and aging process, microinflammation in hypothalamus has started to emerge, due to the activation of several proinflammatory signaling pathways, especially the nuclear factor kappa B (NF- $\mathrm{KB}$ ) and c-Jun N-terminal kinase (JNK)-mediated nuclear transcriptional programs. Together with intracellular organelle stress signals, these pathways develop a chronic microinflammatory environment in the hypothalamus leading to obesity and metabolic disorders.

SUMMARY: Hypothalamic inflammation has been noted not only as an important driver of impaired energy balance, but also contribute in altered neurocircuit functions and promote obesity-associated metabolic impairment.

KEYWORDS: hypothalamus, inflammation, metabolism, obesity, metabolic syndrome

Indones Biomed J. 2020; 12(3): 201-13

\section{Introduction}

Energy homeostasis and nutrient management were highly regulated in a coordinated system in all organisms. Modern human lifestyle has less pressure compared to the early primordial age, including excess nutrients, many new dietary components, accompanied with lack of physical activity, and an increased life span, thank to the exist sophisticated medical system.

However, the evolution impact on the system development of energy homeostasis. A chronic lifetime exposure to the stress signals associated with caloric excess, added with the longer life expectancy, has dramatically increase the requirements for the duration as well as the magnitude of adaptive responses. In some point, the biological response cannot cope anymore to these challenges, the homeostatic systems gradually deteriorate, and metabolic disturbances arose.(1)

From that background, it can be understood that a proper metabolic homeostasis maintenance is crucial for an organism's survival and normal functioning. Regrettably, various environmental and internal interfering factors cannot be avoided most of the time, leads to disruption of metabolic homeostasis. For decades, previous studies focused on nutrition intake imbalance, gut microbiota, and systemic inflammation as the bridge between obesity and metabolic disorders. Apparently, overnutrition, stresses, or diseaseassociated systemic inflammatory factors, and extracellular and intracellular environments of hypothalamic cells result in brain and hypothalamic inflammation leading to central metabolic dysregulations and various diseases.(2)

One reasonable mechanism for this event involves the endoplasmic reticulum (ER), an important organelle for 
protein folding, maturation, quality control, and trafficking. ER could be stressed when there is an imbalance between ER folding capacity and the steady-state unfolded protein pool in the lumen. When accumulated newly synthesized unfolded proteins activate the unfolded protein response (UPR), ER became stressed. Activated UPR, together with oxidative stress, will trigger a variety of inflammatory and stress signaling pathways including nuclear factor kappa $\mathrm{B}(\mathrm{NF}-\kappa \mathrm{B})$-IkB kinase (IKK) and c-Jun N-terminal kinase Activator Protein 1 (JNK-AP1). Inflammation and ER stress are related at many levels, and both are short-term adaptive systems necessary for organisms' function and survival.(1) However, there are numerous physiological or pathological factors induce ER stress, such as nutrient deprivation, redox status, and ER calcium levels.(3) Many evidences since a decade ago showed that dietary (high fat-induced) obesity (4) promote an atypical form of proinflammatory signaling activation, which lead to background-level inflammation in the hypothalamus, known currently as hypothalamic microinflammation.(5) The shifting of the old paradigm of obesity-inflammation-metabolic syndrome which was focused on visceral organs and systemic inflammation, into a new model involving microinflammation in the master regulator of endocrine system, i.e., hypothalamus, will be discussed in this review.

\section{Hypothalamus and Energy Balance}

Eating is now become not only a fundamental mechanism for survival, but also one of the greatest human pleasures and panache. Obesity epidemic grows, particularly in genetically susceptible individuals. Metabolic alteration, central inflammation and ER stress grow interest for studies in the recent years, in association with energy balance.(6) Metabolism regulation in mammals need coordination between tissues and several brain nuclei, mediated by systemic factors and neuronal networks. Hypothalamus is one of the most heterogeneous structures in the central nervous system (CNS), located on the ventral side of the brain symmetrically on both sides of the third ventricle. It contains highly condensed populations of neurons to orchestrate signals from the CNS and the periphery and regulates basic body functions including reproduction, food intake, energy expenditure, defensive responses, control of circadian rhythm and sleepwake cycle.(7-11) As response to metabolic situation, the hypothalamus integrate a multiple signals, either peripheral or central. $(8,9)$ In a situation of altered energy supply (e.g., fasting, post-prandial state), the hypothalamus orchestrates behavioral responses, such as adapted food intake, foodseeking behavior and energy optimization to modify energy expenditure. $(9,10)$

The arcuate nucleus (ARC) is an aggregation of neurons in the mediobasal hypothalamus, contains orexigenic agoutirelated peptide (AgRP)-neuropeptide Y (NPY) neurons and anorexigenic proopiomelanocortin (POMC) neurons. These neurons express receptors for key metabolic regulatory hormones including insulin, leptin, ghrelin, glucocorticoids, estrogen, thyroid hormone and glucagon-like peptide 1 (GLP-1).(12) Leptin is the most notably secreted factors uncovered in the metabolism field since the past two decades, and its dysregulation in the secretion, processing, recognition, or signaling have a role in metabolic disorders. While the ventromedial hypothalamus, which is close to ARC, coupling metabolic sensing to the reproductive control circuit.(13) It expresses not only insulin, leptin and estrogen receptors, but also steroidogenic factor 1 (14) and brain-derived neurotrophic factor (BDNF) (15). Metabolic sensing from the ARC transmit the signals to second-order hypothalamic regions, including the paraventricular nucleus which hosts neuroendocrine neurons that control the stress response, and also the pre-autonomic sympathetic and parasympathetic neurons that can balance the peripheral energy production and expenditure by controlling glucose and lipid metabolism.(16-18)

Any changes in nutritional status will affect the UPR physiological in hypothalamic feeding centers. In response to this, the transcriptional profiles of AgRP and POMC neurons will be altered. In fasting condition, AgRP neurons are activated, accompanied by UPR activation in these neurons, followed by turning on of target genes of X-box binding protein 1 (XBP1) and ER chaperones.(19) The expression of various genes involved in ER protein translocation and golgi trafficking including transcripts encoding activating transcription factor (ATF) 4 and ATF6 were also increased. Furthermore, fasting stimulates the expression of AgRPspecific endoplasmic reticulum-associated degradation (ERAD)-related transcripts. However, fasting-induced changes in the UPR pathway have no significant effect to POMC in producing the anorectic peptide $\alpha$-melanocyte stimulating hormone $(\alpha-\mathrm{MSH})$. Short-term refeeding of fasted mice activating the UPR in POMC neurons and increase the expression of XBP1s, ATF4, and ATF6 in POMC.(20) These suggest that UPR in AgRP and POMC neurons is affected by nutrition in a different way, and give us a clue that fasting-induced activation of AgRP neurons could behave distinctly in POMC neurons suppression. 
The homeostasis regulated by the hypothalamus involving neural, nutritional, and hormonal cues. Hypothalamic neuropeptides play a fundamental role in circadian rhythm, body temperature, thirst, food intake, energy expenditure, and glucose metabolism. Thus, malfunction in CNS network that controls energy management could be the major mechanism for the development of obesity.(21-24) Some studies observed reactive changes in the hypothalamus triggers leptin and insulin resistance, with the involvement of adipocytes and macrophages.(25-29)

\section{Inflammaging}

The sophisticated medical system nowadays increases human's life expectancy, however some of aging process keep going and cannot be completely avoided. Aging is a complex process with deteriorating cellular repair capacity so that the damage at genomic and proteomic levels increased, and impact on essentially all organs. Systemic changes in metabolism during aging lead to proinflammatory cytokine production, resulting in chronic, sterile, low-grade inflammation, called inflammaging (3032). Inflammaging is macrophage-centered, characterized by a complex balance between pro- and antiinflammatory responses, involves a variety of stimuli that fuel it, including persistent pathogens infections such as cytomegalovirus or periodontitis (non-self), endogenous cell debris and misplaced or altered molecules (self) and nutrients and gut microbiota (quasi-self).(33) Within this framework, the gut microbiota is of particular and crucial importance, as it roles as the gate between diet, metabolism and the innate immune response, and it experience a profound remodelling with age.(31) Collectively, inflammaging has similar character to metaflammation (the metabolic inflammation driven by overnutrition, present in metabolic diseases), thus metaflammation is considered as an accelerated aging.(31)

Nutrients and pathogens are two most factors determine an organism's survival. Therefore, the ecological dynamics of populations and species and evolution largely determined by the events of food competition and the response to infectious diseases.(34-36) Thus, food sources, metabolism, endocrine responses, innate immune responses and inflammation were co-evolved with macrophage as the master cell at the interface between metabolism and immunity.(37) Some evidences suggest the co-evolving of immune, metabolic and endocrine responses. First, the overlap between macrophages and adipocytes. Both secrete similar cytokines and can be activated by bacterial products, such as lipopolysaccharide (38); moreover, preadipocytes can transdifferentiate into macrophages $(39,40)$. Second, Drosophila melanogaster's body fat constitutes the functional unit that activates both metabolic and immune responses, suggesting that they evolved from a common ancestral structure. $(41,42)$ Third, nutrition considered to activate the immune response, due to the heavily contaminated food and water with microbial stimuli. Fourth, when that food was ingested, it will activate innate immunity response, called postprandial inflammation, and when it became part of the adaptive response to meals, by several molecular mechanisms the inflammatory markers increased. $(41,43)$

\section{Astrocytes: Key Regulators of Neuroinflammation}

Represents only $2 \%$ of total body mass, the brain requires about $20 \%$ of the oxygen and $25 \%$ of the consumed glucose to run its function. Due to its high energy consumption and lack of ability to store energy, the brain is often considered to be a 'selfish' organ. The high energy needs of cerebral particularly use for the maintenance and restoration of ion gradients which utilized by signaling processes such as post-synaptic and action potentials, uptake and recycling of neurotransmitters. $(44,45)$ The mechanisms regulated tightly to ensure adequate spatial and temporal delivery of energy substrates is appropriate to the neuronal activity. When the brain senses a decreased of its energy supply, it will initiate energy-producing including food intake and mobilization of peripheral energy stores, aim to increase the circulating glucose as the brain's major energy resource. However, this does not apply otherwise. In the state of peripheral energy excess, such as obesity, the brain does not act to reduce energy intake. Thus, many presumption conclude that abnormalities of brain sensing of peripheral adiposity feedback information such as leptin resistance, and any defect in transport of circulating metabolic factors across the blood-brain barrier (BBB) play roles in obesity development. $(46,47)$ This supported by the fact that leptin resistance involves decreased leptin passage across the BBB.(48)

Astrocytes, are a major class of macroglial cells which occupy up to $50 \%$ of the total brain volume and play major roles in brain homeostasis as active players in the brain energy delivery, production, utilization, and storage.(46) Classically, astrocytes known 
as structural neuronal supportive elements, but now identified to participate in a wider function such as providing metabolites for neuronal proliferation and differentiation, support synapse formation and plasticity, modulation of synaptic efficacy, ionic and neurotransmitter homeostasis maintenance, and functional hyperemia as described in Figure 1.(49,50)

Astrocytes located strategically close to the CNSresident cells (neurons, microglia, oligodendrocytes and other astrocytes) and blood vessels, therefore it also participate in BBB maintenance and permeability. Astrocytes also take part in innate and adaptive immune responses regulation in the injured CNS by controlling the immune cell trafficking and activation. Astrocytes are immune-competent cells which able to detect danger signals, respond via secretion of cytokines and chemokines, and activate adaptive immune defense Their activity could either provoke inflammatory reactions and tissue damage, or promote immunosuppression and tissue repair depend on timing and context.(51-55)

During a High Fat-Diet (HFD) challenge, neurons utilize less glucose and astrocytes more actively utilize metabolite ketone bodies (56), the same phenomenon as in starvation where energy homeostasis maintenance switch to lipids utilization. Monocarboxylate transporter-1 (MCT-1) is the transporter of ketone bodies, both into and out of cells.(57) In brain tissue, MCT-1 is exclusively expressed by astrocytes (58) and upregulation of MCT-1 is associated with astrocyte activation (reactive gliosis) (59). Moreover, high concentrations of circulating ketone bodies also increase MCT-1.(60) The hypothalamus of HFD-fed rats showed active astrocytosis (61), suggests it was the consequence of circulating ketone bodies.

Some studies showed that astrocytes express ghrelin receptors, and respond to this hormone and its analogs.(6264). Ghrelin often called as a hunger hormone, released by gastrointestinal tract, pancreas, and brain. The increased levels of ghrelin in circulation promote a sensation of hunger. It modulates systemic metabolism through activation of orexigenic neural circuits in the hypothalamus.(65-68) Ghrelin receptors found on hypothalamic neurons regulate food intake and satiety $(69,70)$, and the receptors in nonhypothalamic brain regions contribute to eating behavior (71). Several evidences support its function in modulating the reward systems (72,73), learning and memory performance $(74,75)$, and playing a protective role against

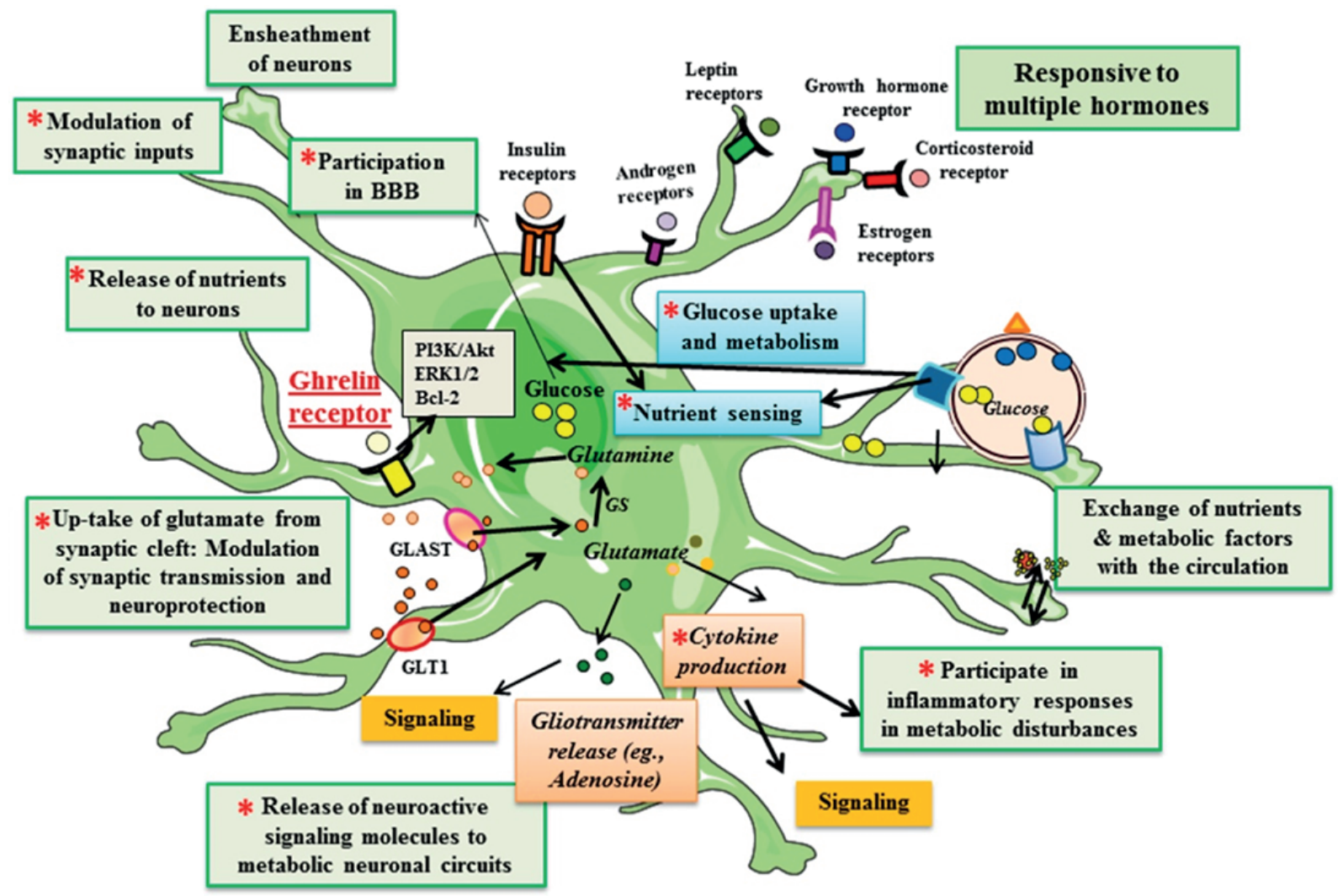

Figure 1. Schematic representation of the various functions attributed to astrocytes.(51) (Adapted with permission from MDPI). BBB: blood-brain barrier; PI3K: phosphatidylinositol 3-kinase; ERK: extracellular receptor kinase; Bcl-2: B-cell lymphoma 2; GLAST: glutamate/aspartate transporter; GLT1: glutamate transporter 1. 
degenerative diseases $(76,77)$. However, the effects are mainly mediated through ghrelin responsive neurons.(51)

Regardless of its function to ensure normal brain development and neural functioning (78), recent studies showed increased attention in astrocytes role on both physiological and pathophysiological processes related to metabolic control (79-81). Indeed, numerous trophic factors and hormones expressed by these glial cells. NF- $\mathrm{KB}$ is a crucial transcription factor in any inflammatory reaction. Activation of NF- $\kappa B$ and NF- $\kappa B$-dependent transcription of pro-inflammatory factors are relevant for both inflammatory and neurodegenerative processes.(82) Neuroinflammation refers to the activation of the brain's innate immune system in response to an inflammatory challenge. It involves a complex integration of all CNS cells activity, including neurons, glia cells and, eventually, infiltrating immune cells. A study dissect the contribution of astroglial $\mathrm{NF}-\kappa \mathrm{B}$ to CNS neuroinflammation, and observed that a dominant negative form of $\mathrm{Ik} \beta /$ overexpressing in mouse glia cells blocks nuclear translocation of NF-kB.(83) $\mathrm{NF}-\kappa \mathrm{B}$ inactivation in astrocytes improves the clinical outcome in neuroinflammation including spinal cord injury (SCI) (83), experimental autoimmune encephalomyelitis (EAE) (83-85), nerve injury (86), brain injury $(87,88)$ and retinal ischemia $(89,90)$. Astrocytes may promote or dampen neuronal damage, demyelination, and inflammation depending on the kind of stimuli and effector mechanisms present in the inflamed milieu.(51)

During neuroinflammation, interleukin (IL)-17 is released by effector $\mathrm{T}$ lymphocytes, and astrocytes upregulate the receptor.(91) After IL-7 bound to its heteromeric transmembrane receptors, NF- $\mathrm{kB}$ activator 1 (Act1) recruited, thus a signaling complex triggers the production of pro-inflammatory cytokines, chemokines and metalloproteinases.(92) Another important signaling pathway in astrocytes with pathological setting involves sphingolipids, including sphingosine 1-phosphate (S1P) and lactosylceramide (LacCer) (Figure 2). S1P binds to specific G-protein-coupled receptors (S1P1-5) and regulates cellular processes such as growth, survival and differentiation. S1PS1P1 axis controls leukocyte trafficking from the lymphoid tissues to blood circulation.(93) In multiple sclerosis and EAE, S1P receptors are strongly upregulated on activated glia cells. $(91,94)$ The pathogenicity of S1P1 signaling in astrocytes indicated when its lack in mice astrocytes showed ameliorated EAE expression, reduced demyelination and axonal loss.(95)

Accumulating data showed that astrocytes also express PPAR- $\gamma$, which plays important roles as a sensor and regulator in lipid metabolism.(96) Astrocytes has a close relationship with leptin receptor-expressing neurons, indicate its possible role as a central sensor of systemic energy availability.

\section{ER Stress and The Inflammatory Basis of Metabolic Disease}

ER is the central site for protein folding and trafficking to perform many cellular functions. UPR activation is the results of ER's adaptive capacity failure, which crosscut with many different inflammatory and stress signaling pathways and participate in chronic metabolic diseases such as obesity, insulin resistance, and type 2 diabetes mellitus (T2DM).(1)

Many evidences showed a close relation between ER stress and obesity-associated insulin resistance in peripheral tissues, including the pancreas and liver.(9799) ER stress in the hypothalamus occurs in a state of hyper-nutrition, such as obesity and T2DM, leading to leptin and insulin resistance.(27,100-103) Recent studies demonstrated that genetic or pharmacologic improvement of protein folding ameliorate the hypothalamic ER stress and improve leptin and insulin sensitivity.(27,100-105) On the contrary, central ceramide-induced lipotoxicity induces ER stress and promote weight gain, glucose intolerance, decreased sympathetic tone, and brown adipose tissue (BAT) thermogenesis.(102,105-107) Ceramide is a key intermediate of sphingolipid metabolite that couples HFD consumption to ER stress. The hypothalamic level of ceramide is elevated in obesity.(108) However, a study showed that over-expression of glucose-regulated protein (GRP78; also called BiP) and its dominant negative mutant, specifically in the ventromedial nucleus of the hypothalamus (VMH) can reverse these responses and lead to weight loss, reduced hepatic steatosis also improved insulin and leptin sensitivity.(101) Another strategy to reduce body weight is to increase energy expenditure (109-114), and recent interest has focused on the activation of the thermogenic process, especially to control BAT activity $(111,115-118)$, as well as the browning process of white adipose tissue (WAT) into beige/brown-in-white (brite) adipocytes (114,119-121).

The disruption in ER homeostasis is communicated to the nucleus and the translational machinery via a set of signaling routes collectively called the UPR. There are three distinct transmembrane which act as ER stress sensors, which also serve as UPR main branches (Figure 3): protein kinase R (PKR)-like ER kinase (PERK; also known 


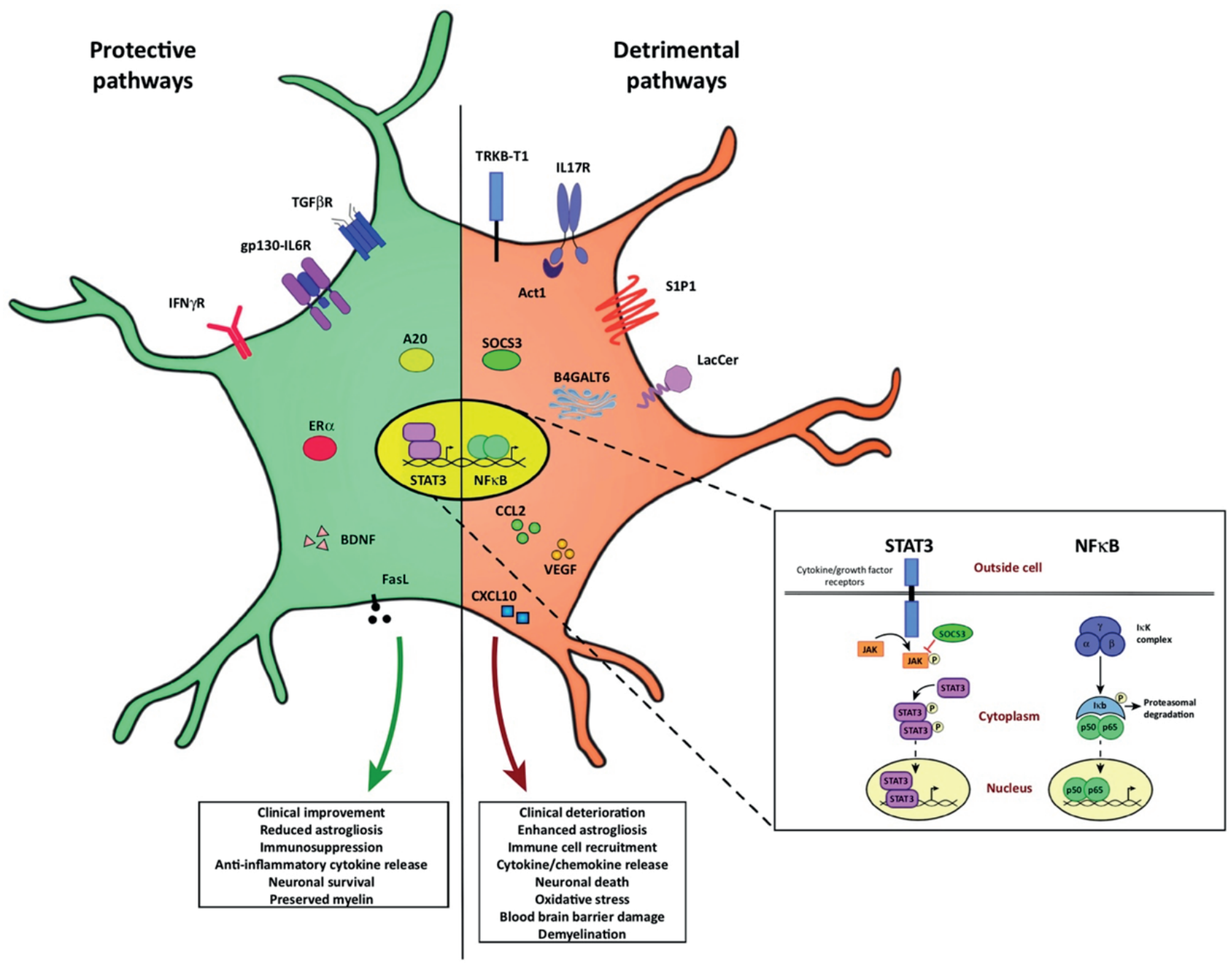

Figure 2. Impact of astrocyte perturbations on neuroinflammation.(52) (Adapted with permission from Elsevier). TGF $\beta R$ : transforming growth factor-beta receptor; gp130-IL6R: glycoprotein 130-interleukin-16 receptor; IFN- $\gamma \mathrm{R}$ : interferon-gamma receptor; ER $\alpha$ : estrogen receptors alpha; BDNF: brain-derived neurotrophic factor; FasL: Fas ligand; TRKB-T1: tropomyosin receptor kinase B-T1; IL17R: interleukin-17 receptor; S1P1: sphingosine 1-phosphate 1; LacCer: lactosylceramide; SOCS3: suppressor of cytokine signaling 3; B4GALT6: beta-1,4-galactosyltransferase 6; CCL2: C-C motif chemokine ligand 2; VEGF: vascular endothelial growth factor; CXCL10: C-X-C motif chemokine ligand 10; STAT3: signal transducer and activator of transcription 3; NF-kB: nuclear factor-kappa B.

as the eukaryotic translation initiation factor 2a kinase 3), inositol-requiring enzyme 1 (IRE1), and ATF6.(21) HFDinduced obese rodents increase ER stress markers including IRE1 and PERK phosphorylation, XBP1 splicing, and C/ EBP homologous protein (CHOP) and GRP78 expression $(27,122,123)$, indicates that dietary composition have a role in hypothalamic ER stress induction. Several data demonstrated that saturated fatty acids such as palmitate activate hypothalamic ER stress and attenuate leptin and insulin receptor signaling.(124-126) Toll-like receptor 4 (TLR4) is a receptor for saturated fatty acids, and central infusion of palmitate activate TLR4 then induces inflammatory cytokine expression and ER stress. $(127,128)$
Oppositely, neuronal (but not global) ablation of the TLR4 adapter protein MyD88 prevents excess weight gain in mice on a HFD. $(108,129)$

Mitochondria-associated membranes (MAMs) is a region connecting the ER and mitochondria, functionally and metabolically, and the crosstalk between both are maintained by mitofusin 2 (MTF2) protein. $(130,131)$ Thus, MAMs disruption might impair ER and mitochondria integration and impact in metabolic failure. MTF2 is a membrane protein that coordinating body energy homeostasis by regulating ER homeostasis in pairing to mitochondrial activity.(130) MTF2 expression is affected by nutrition. Lipotoxic insult by HFD intake in rodents and in vitro stimulation of muscle 


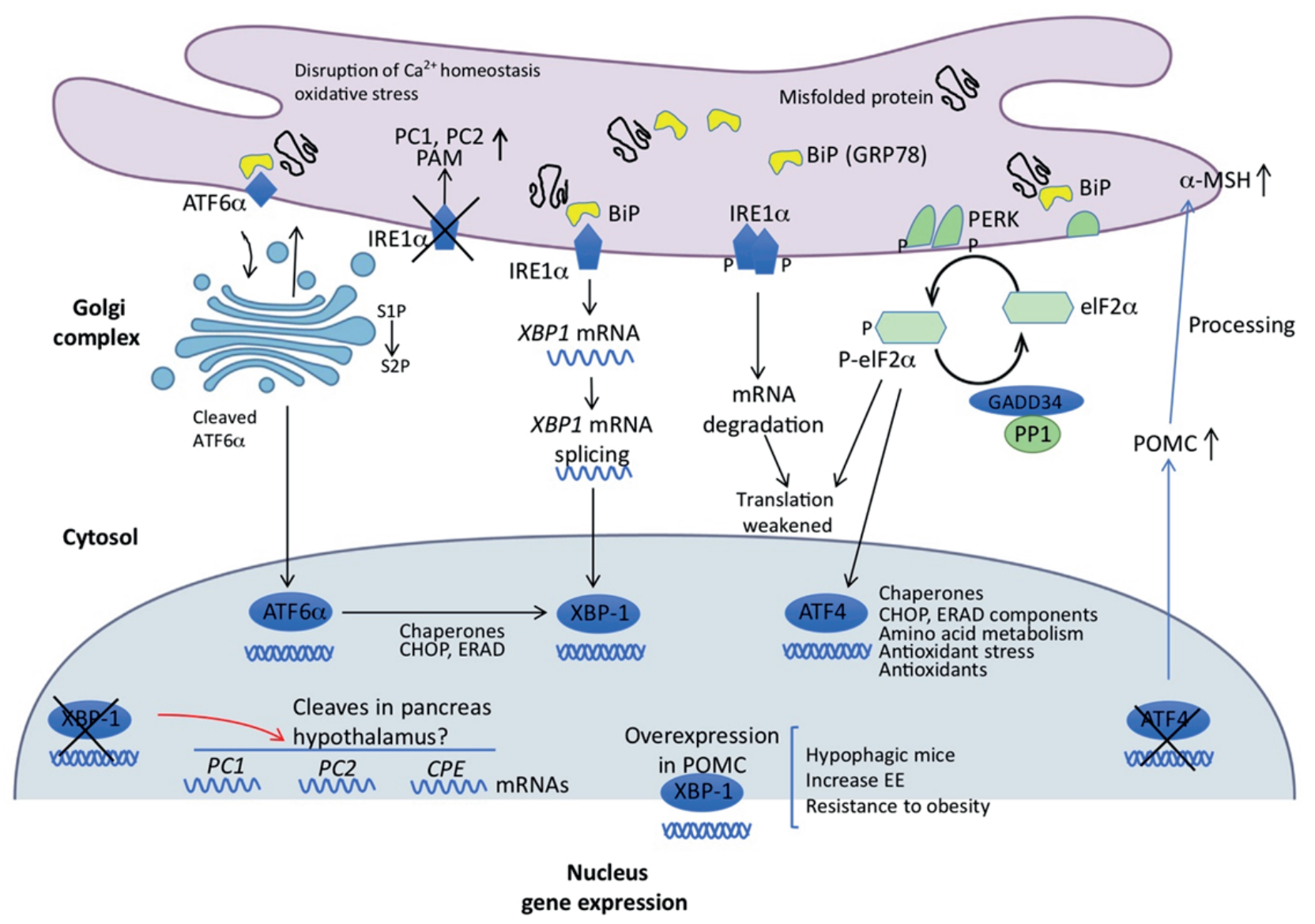

Figure 3. The UPR is composed of three arms that are each initiated by distinct ER membrane proteins: PERK, IRE1, and ATF6.(21) (Adapted with permission from Elsevier). ATF6 $\alpha$ : activating transcription factor 6-alpha; PC: proprotein convertase; IRE1 $\alpha$ : inositol-requiring enzyme 1-alpha; GRP78/BiP: glucose-regulated protein; PERK: PKR-like ER kinase; XBP1: X-box binding protein 1; eIF2 $\alpha$ : eukaryotic initiation factor 2-alpha; S1P: sphingosine 1-phosphate; POMC: proopiomelanocorin; CHOP: C/EBP homologous protein; ERAD: endoplasmic reticulum-associated degradation.

cells with the saturated lipid palmitic acid decreases MTF2 gene expression and protein levels in skeletal muscle and arcuate nucleus of hypothalamus, correlates with downregulation in the expression of antioxidant enzymes, oxidative stress activation and JNK and NF- $\mathrm{KB}$ activation lead to insulin resistance. $(132,133)$

Excess calorie intake and adiposity clearly correlate with inflammation in CNS. Obesity and inflammation showed a positive feedback loop where inflammation induce various abnormalities observed in obesity. On the other side, inflammation also functionally coupled with ER stress in initiating metabolic disorders. Activated IKK $\beta$ NF- $\mathrm{KB}$ signaling increases the expression of Suppressor of cytokine signaling 3 (SOCS3), impact in insulin and leptin signaling. Suggest that hypothalamic IKK $\beta$ and ER stress can activate each other, also forming a positive feedback loop and promote dysregulation of central energy balance. Thus, the hypothalamic IKK $\beta-\mathrm{NF}-\kappa \mathrm{B}$ axis couples ER stress to central inflammation.

\section{Hypothalamic Microinflammation: A Common Basis Of Metabolic Syndrome}

Hypothalamus regulate the energy homeostasis according to the input from metabolic feedback signals such as insulin and leptin.(134) Inflammation process could activate in hypothalamus in diet-induced obesity, such as in a study of three days of HFD feeding apparently is sufficient to initiate the early occurrence of inflammation and significantly reduce hypothalamic insulin sensitivity in rodents.(135) Notably, the inflammation occurred first in peripheral tissues, such as the liver.(136,137) The hypothalamic inflammation occurs in two phases, started by an early and transient inflammation, increased inflammatory markers even since the first day of HFD, and if the HFD exposure is sustained, the secondary phases activated which is a prolonged inflammatory cascade that lead to the activation of cellular stress mechanisms. The reactive gliosis and neuronal injury 
manifesting during the first week, even before the body weight gain and metabolic syndrome.(138) Metabolic syndrome is a cluster of interrelated pathophysiological metabolic disorders including obesity, hyperglycemia, insulin resistance, hyperlipidemia and hypertension, which all serve as a pathogenic soil for T2DM and cardiovascular disease (CVD).(5) Therefore, hypothalamus is the key of the orchestrated actions of neural pathways and neuroendocrine hormones on energy homeostasis regulation (139-146), and nutritional status exerts important feeder for hypothalamic signaling $(23,47,147-152)$.

Hypothalamic inflammatory process comprises hundreds of inflammatory genes, including tumor necrosis factor- $\alpha$ (TNF- $\alpha$ ) and interleukins among a lot more to be characterized, which are dynamic during the disease development. The molecular changes often result in hypothalamic low-level NF- $\mathrm{KB}$ activation, commonly known as hypothalamic microinflammation and mediate the core features of overnutrition-triggered metabolic syndrome. (153-161) Overnutrition also triggers local ER stress which further activate UPR downstream cascades which interact with the inflammatory molecules including IKK $\beta / \mathrm{NF}-\kappa \mathrm{B}$ and JNK-AP1 pathways and the oxidative stress pathways too and finally contribute to promote hypothalamic NF- $\kappa \mathrm{B}$ inflammation. $(27,118)$ Combination of these interaction cause central insulin and leptin resistance.(27) Chronic overnutrition state or aging process induce a state known as metaflammation and inflammaging consecutively (Figure 4), which precipitate hypothalamic micro-inflammation

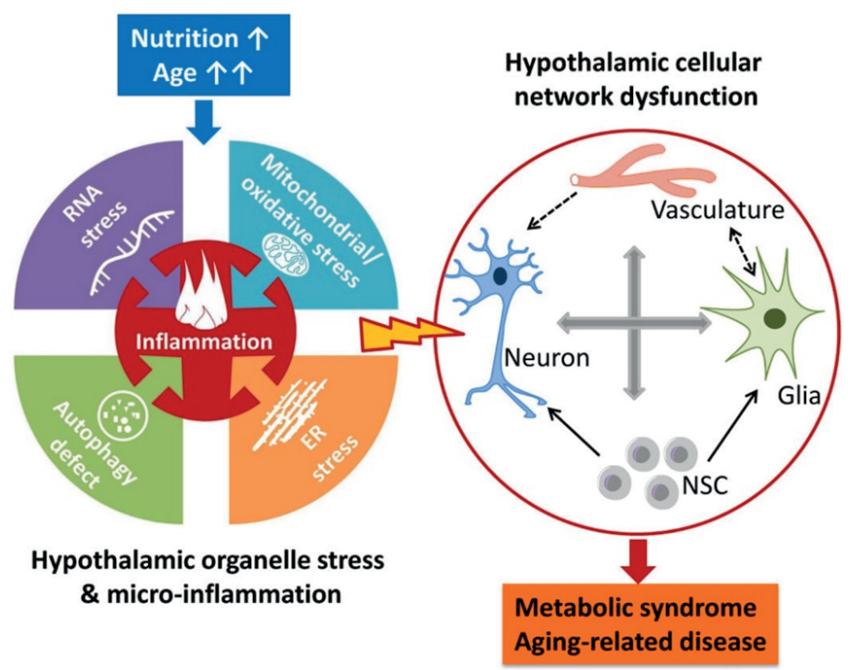

Figure 4. Intracellular and cellular networks of hypothalamic micro-inflammation under chronic overnutrition or aging.(5) (Adapted with permission from Elsevier) through neuronal interactions, and crosstalk between gliaglia and neuron-glia, affects on blocking the hypothalamic regulatory functions as well as hypothalamic neural stem cell (NSC)-directed neurogenesis. Chronically, these will develop metabolic dysfunctions and aging related disorders.

Glial cells, are non-neuronal supportive cells that constitute neural microenvironment, form myelin, and provide support and protection for neurons. Types of glial cells include oligodendrocytes, astrocytes, ependymal cells, Schwann cells, microglia, and satellite cells. Recent data showed that gliotransmission in glial cells $(162,163)$ mediate the neuroinflammatory response (164). Excess production of hypothalamic astrocytes transforming growth factor beta (TGF- $\beta$ ) in obesity and aging conditions influence in the decay of $\mathrm{I} \kappa \beta \alpha$ mRNA, thus activating proinflammatory NF- $\kappa \mathrm{B}$ in the hypothalamus and promote diabetes development.(165)

Increasing studies in overnutrition-induced hypothalamic microinflammation convince that such atypical inflammatory changes in the hypothalamus are pathologically important for overnutrition-related diseases, mostly involving two neuronal subpopulations in the mediobasal hypothalamus POMC and AgRP. Hypothalamic microinflammation, is associated with pancreatic $\beta$ cells impaired insulin release, and the development of renovascular dysfunction leading to hypertension, independently of body weight (Figure 5). When the body sense fat gain, leptin and also insulin secretion from pancreatic beta cells will be increased, which inhibit AgRP and activate POMC neurons, leading to decreased energy intake and increased energy expenditure and therefore keep the body weight homeostasis. Somehow, the mechanism is compromised during the development of obesity, suggest that chronic nutritional challenge blunt the leptin and insulin signaling in the hypothalamus, suggested due to NF- $\kappa \beta$-dependent inflammatory changes in the mediobasal hypothalamus. It was reported that hypothalamic AgRP neuron-specific IKK $\beta$ ablation provided protective effects against hyperphagia, obesity and glucose intolerance.(27)

\section{Conclusion}

'Hypothalamic microinflammation' refer to atypical proinflammatory signaling activation in hypothalamus induced by inflammaging and metaflammation. During the past decade, the understanding of hypothalamic microinflammation in metabolic syndrome and aging has been further advanced. Non-neuronal cells in the 


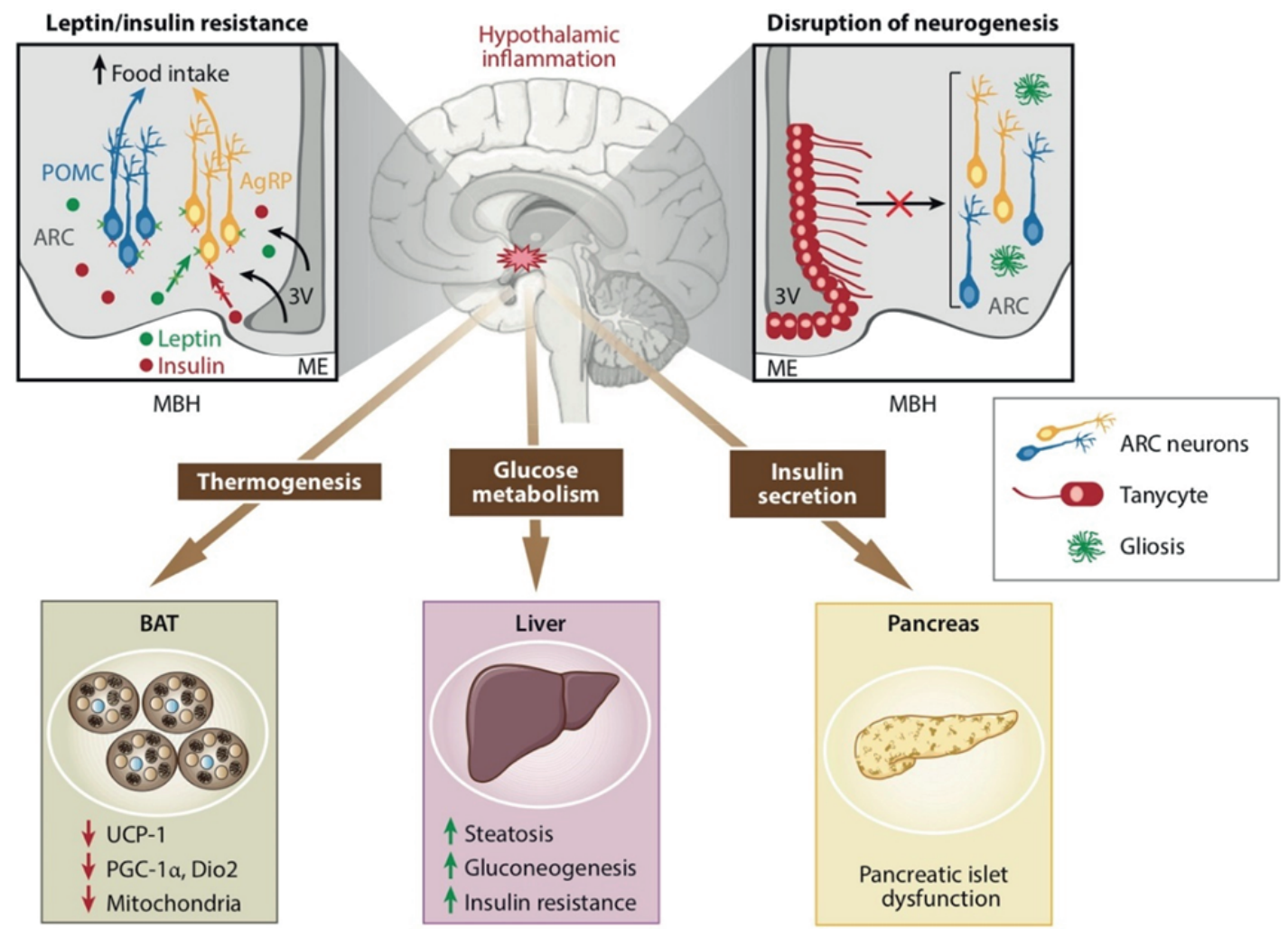

Figure 5. The impact of metabolic inflammation in the mediobasal hypothalamus on the neurocircuitry controlling energy balance and processes that maintain hypothalamic architecture.(166) (Adapted with permission from Annual Review). POMC: proopiomelanocortin; ARC: arcuate nucleus; AgRP: agouti-related peptide; MBH: membrane-bound hydrogenase; BAT: brown adipose tissue; UCP-1: uncoupling protein 1; PGC-1 $\alpha$ : peroxisome proliferator-activated receptor gamma coactivator 1-alpha; Dio2: iodothyronine deiodinase 2.

hypothalamus are involved in hypothalamic inflammation and dysregulations, lead to metabolic syndrome. Thus, Hypothalamic inflammation has been noted not only as an important driver of impaired energy balance, but also contribute in altered neurocircuit functions and promote metabolic disorders.

\section{References}

1. Hotamisligil GS. Endoplasmic reticulum stress and the inflammatory basis of metabolic disease. Cell. 2010; 140: 900-17.

2. Cai D, Liu T. Hypothalamic inflammation: a double-edged sword to nutritional diseases. Ann NY Acad Sci. 2011; 1243: E1-39.

3. Kaufman RJ. Orchestrating the unfolded protein response in health and disease. J Clin Invest. 2002; 110: 1389-98.

4. Gao F, Yokoyama S, Fujimoto M, Tsuneyama K, Saiki I, Shimada Y, et al. Effect of keishibukuryogan on genetic and dietary obesity models. Evid Based Complementary Altern Med. 2015; 2015: e801291. doi: 10.1155/2015/801291.

5. Tang Y, Purkayastha S, Cai D. Hypothalamic microinflammation: a common basis of metabolic syndrome and aging. Trends Neurosci. 2015; 38: 36-44.

6. Cakir L, Nillni EA. Brain inflammation and endoplasmic reticulum stress. In: Nillni EA, editor. Textbook of Energy Balance,
Neuropeptide Hormones, and Neuroendocrine Function. 1st ed. New York: Springer International Publishing; 2018. p. 75-108.

7. Vercruysse P, Vieau D, Blum D, Petersén Å, Dupuis L. Hypothalamic alterations in neurodegenerative diseases and their relation to abnormal energy metabolism. Front Mol Neurosci. 2018; 11: 2. doi: 10.3389/fnmol.2018.00002.

8. Berthoud HR. Multiple neural systems controlling food intake and body weight. Neurosci Biobehav Rev. 2002; 26: 393-428.

9. Timper K, Brüning JC. Hypothalamic circuits regulating appetite and energy homeostasis: pathways to obesity. Dis Model Mech. 2017; 10: 679-89.

10. Morton GJ, Meek TH, Schwartz MW. Neurobiology of food intake in health and disease. Nat Rev Neurosci. 2014; 15: 367-78.

11. Yi C, Zeltser L, Tschöp M. Metabolic Syndrome ePoster-Brain \& Neuron. EPoster presented at: Nature Medicine; 2011.

12. Yi CX, Tschöp MH. Brain-gut-adipose-tissue communication pathways at a glance. Dis Model Mech. 2012; 5: 583-7.

13. Yi CX, Scherer T, Tschöp MH. Cajal revisited: does the VMH make us fat? Nat Neurosci. 2011; 14: 806-8.

14. Kim KW, Li S, Zhao H, Peng B, Tobet SA, Elmquist JK, et al. CNSspecific ablation of steroidogenic factor 1 results in impaired female reproductive function. Mol Endocrinol Baltim Md. 2010; 24: 124050 .

15. Xu B, Goulding EH, Zang K, Cepoi D, Cone RD, Jones KR, et al. Brain-derived neurotrophic factor regulates energy balance downstream of melanocortin-4 receptor. Nat Neurosci. 2003; 6: 736-42. 
16. Obici S, Zhang BB, Karkanias G, Rossetti L. Hypothalamic insulin signaling is required for inhibition of glucose production. Nat Med. 2002; 8: 1376-82.

17. Bruinstroop E, la Fleur SE, Ackermans MT, Foppen E, Wortel $\mathrm{J}$, Kooijman $\mathrm{S}$, et al. The autonomic nervous system regulates postprandial hepatic lipid metabolism. Am J Physiol Endocrinol Metab. 2013; 304: E1089-96.

18. Lam TKT, Pocai A, Gutierrez-Juarez R, Obici S, Bryan J, AguilarBryan L, et al. Hypothalamic sensing of circulating fatty acids is required for glucose homeostasis. Nat Med. 2005; 11: 320-7.

19. Henry FE, Sugino K, Tozer A, Branco T, Sternson SM. Cell typespecific transcriptomics of hypothalamic energy-sensing neuron responses to weight-loss. eLife. 2015; 4: e09800. doi: 10.7554/ eLife.09800.

20. Williams KW, Liu T, Kong X, Fukuda M, Deng Y, Berglund ED, et al. Xbp1s in Pomc neurons connects ER stress with energy balance and glucose homeostasis. Cell Metab. 2014; 20: 471-82.

21. Cakir I, Nillni EA. Endoplasmic reticulum stress, the hypothalamus, and energy balance. Trends Endocrinol Metab TEM. 2019; 30: 16376.

22. Zhang Y, Proenca R, Maffei M, Barone M, Leopold L, Friedman JM. Positional cloning of the mouse obese gene and its human homologue. Nature. 1994; 372: 425-32.

23. Williams KW, Elmquist JK. From neuroanatomy to behavior: central integration of peripheral signals regulating feeding behavior. Nat Neurosci. 2012; 15: 1350-5.

24. Begg DP, Woods SC. The endocrinology of food intake. Nat Rev Endocrinol. 2013; 9: 584-97.

25. Furuhashi M, Fucho R, Görgün CZ, Tuncman G, Cao H, Hotamisligil GS. Adipocyte/macrophage fatty acid-binding proteins contribute to metabolic deterioration through actions in both macrophages and adipocytes in mice. J Clin Invest. 2008; 118: 2640-50.

26. Mathis D. Immunological goings-on in visceral adipose tissue. Cell Metab. 2013; 17: 851-9.

27. Zhang X, Zhang G, Zhang H, Karin M, Bai H, Cai D. Hypothalamic IKKbeta/NF-kappaB and ER stress link overnutrition to energy imbalance and obesity. Cell. 2008; 135: 61-73.

28. De Souza CT, Araujo EP, Bordin S, Ashimine R, Zollner RL, Boschero AC, et al. Consumption of a fat-rich diet activates a proinflammatory response and induces insulin resistance in the hypothalamus. Endocrinology. 2005; 146: 4192-9.

29. Kälin S, Heppner FL, Bechmann I, Prinz M, Tschöp MH, Yi CX. Hypothalamic innate immune reaction in obesity. Nat Rev Endocrinol. 2015; 11: 339-51.

30. Gregor MF, Hotamisligil GS. Inflammatory mechanisms in obesity. Annu Rev Immunol. 2011; 29: 415-45.

31. Franceschi C, Garagnani P, Parini P, Giuliani C, Santoro A. Inflammaging: a new immune-metabolic viewpoint for age-related diseases. Nat Rev Endocrinol. 2018; 14: 576-90.

32. van Beek AA, Van den Bossche J, Mastroberardino PG, de Winther MPJ, Leenen PJM. Metabolic Alterations in aging macrophages: ingredients for inflammaging? Trends Immunol. 2019; 40: 113-27.

33. Franceschi C, Garagnani P, Vitale G, Capri M, Salvioli S. Inflammaging and "garb-aging." Trends Endocrinol Metab TEM. 2017; 28: 199-212.

34. Darwin CR. On the Origin of Species by Means of Natural Selection, or The Preservation of Favoured Races in the Struggle for Life. 1st ed. London: John Murray; 1859.

35. Fumagalli M, Sironi M, Pozzoli U, Ferrer-Admettla A, Pattini L, Nielsen R. Signatures of environmental genetic adaptation pinpoint pathogens as the main selective pressure through human evolution. PLOS Genet. 2011; 7: e1002355. doi: 10.7554/eLife.09800.001.
36. Vasseur E, Quintana-Murci L. The impact of natural selection on health and disease: uses of the population genetics approach in humans. Evol Appl. 2013; 6: 596-607.

37. Ottaviani E, Franceschi C. The invertebrate phagocytic immunocyte: clues to a common evolution of immune and neuroendocrine systems. Immunol Today. 1997; 18: 169-74.

38. Chung S, Lapoint K, Martinez K, Kennedy A, Boysen Sandberg M, McIntosh MK. Preadipocytes mediate lipopolysaccharide-induced inflammation and insulin resistance in primary cultures of newly differentiated human adipocytes. Endocrinology. 2006; 147: 534051.

39. Charrière G, Cousin B, Arnaud E, André M, Bacou F, Pénicaud L, et al. Preadipocyte conversion to macrophage: evidence of plasticity. J Biol Chem. 2003; 278: 9850-5.

40. Hotamisligil GS, Erbay E. Nutrient sensing and inflammation in metabolic diseases. Nat Rev Immunol. 2008; 8: 923-34.

41. Hotamisligil GS. Inflammation and metabolic disorders. Nature. 2006; 444: 860-7.

42. Hotamisligil GS. Inflammation, metaflammation and immunometabolic disorders. Nature. 2017; 542: 177-85.

43. Ye J, Keller JN. Regulation of energy metabolism by inflammation: a feedback response in obesity and calorie restriction. Aging. 2010; 2 : 361-8

44. Attwell D, Laughlin SB. An energy budget for signaling in the grey matter of the brain. J Cereb Blood Flow Metab Off J Int Soc Cereb Blood Flow Metab. 2001; 21: 1133-45.

45. Alle H, Roth A, Geiger JRP. Energy-efficient action potentials in hippocampal mossy fibers. Science. 2009; 325: 1405-8.

46. Bélanger M, Allaman I, Magistretti PJ. Brain energy metabolism: focus on astrocyte-neuron metabolic cooperation. Cell Metab. 2011; 14: 724-38

47. Yi CX, Habegger KM, Chowen JA, Stern J, Tschöp MH. A role for astrocytes in the central control of metabolism. Neuroendocrinology. 2011; 93: 143-9.

48. Banks WA. Blood-brain barrier as a regulatory interface. Forum Nutr. 2010; 63: 102-10

49. Haydon PG, Carmignoto G. Astrocyte control of synaptic transmission and neurovascular coupling. Physiol Rev. 2006; 86: 1009-31.

50. Filosa JA, Blanco VM. Neurovascular coupling in the mammalian brain. Exp Physiol. 2007; 92: 641-6.

51. Frago LM, Chowen JA. Involvement of astrocytes in mediating the central effects of ghrelin. Int J Mol Sci. 2017; 18: 536. doi: 10.3390/ ijms 18030536 .

52. Colombo E, Farina C. Astrocytes: key regulators of neuroinflammation Trends Immunol. 2016; 37: 608-20.

53. Sofroniew MV. Molecular dissection of reactive astrogliosis and glial scar formation. Trends Neurosci. 2009; 32: 638-47.

54. Cordiglieri C, Farina C. Astrocytes exert and control immune responses in the brain. Curr Immunol Rev. 2010; 6: 150-9.

55. Farina C, Aloisi F, Meinl E. Astrocytes are active players in cerebral innate immunity. Trends Immunol. 2007; 28: 138-45.

56. Melø TM, Nehlig A, Sonnewald U. Neuronal-glial interactions in rats fed a ketogenic diet. Neurochem Int. 2006; 48: 498-507.

57. Halestrap AP, Price NT. The proton-linked monocarboxylate transporter (MCT) family: structure, function and regulation. Biochem J. 1999; 343: 281-99.

58. Bröer S, Rahman B, Pellegri G, Pellerin L, Martin JL, Verleysdonk $\mathrm{S}$, et al. Comparison of lactate transport in astroglial cells and monocarboxylate transporter 1 (MCT 1) expressing Xenopus laevis oocytes. Expression of two different monocarboxylate transporters in astroglial cells and neurons. J Biol Chem. 1997; 272: 30096-102. 
59. Lin T, Koustova E, Chen H, Rhee PM, Kirkpatrick J, Alam HB. Energy substrate-supplemented resuscitation affects brain monocarboxylate transporter levels and gliosis in a rat model of hemorrhagic shock. J Trauma. 2005; 59: 1191-202.

60. Leino RL, Gerhart DZ, Duelli R, Enerson BE, Drewes LR. Dietinduced ketosis increases monocarboxylate transporter (MCT1) levels in rat brain. Neurochem Int. 2001; 38: 519-27.

61. Horvath TL, Sarman B, García-Cáceres C, Enriori PJ, Sotonyi $\mathrm{P}$, Shanabrough $\mathrm{M}$, et al. Synaptic input organization of the melanocortin system predicts diet-induced hypothalamic reactive gliosis and obesity. Proc Natl Acad Sci USA. 2010; 107: 14875-80.

62. Baquedano E, Chowen JA, Argente J, Frago LM. Differential effects of $\mathrm{GH}$ and GH-releasing peptide- 6 on astrocytes. J Endocrinol. 2013; 218: 263-74.

63. Fuente-Martín E, García-Cáceres C, Argente-Arizón P, Díaz F, Granado M, Freire-Regatillo A, et al. Ghrelin regulates glucose and glutamate transporters in hypothalamic astrocytes. Sci Rep. 2016; 6: 23673. doi: $10.1038 /$ srep23673.

64. García-Cáceres C, Fuente-Martín E, Díaz F, Granado M, ArgenteArizón P, Frago LM, et al. The opposing effects of ghrelin on hypothalamic and systemic inflammatory processes are modulated by its acylation status and food intake in male rats. Endocrinology. 2014; 155: 2868-80.

65. Cowley MA, Smith RG, Diano S, Tschöp M, Pronchuk N, Grove KL, et al. The distribution and mechanism of action of ghrelin in the CNS demonstrates a novel hypothalamic circuit regulating energy homeostasis. Neuron. 2003; 37: 649-61.

66. Müller TD, Nogueiras R, Andermann ML, Andrews ZB, Anker SD, Argente J, et al. Ghrelin. Mol Metab. 2015; 4: 437-60.

67. Nakazato M, Murakami N, Date Y, Kojima M, Matsuo H, Kangawa $\mathrm{K}$, et al. A role for ghrelin in the central regulation of feeding. Nature. 2001; 409: 194-8.

68. Schmid SM, Hallschmid M, Jauch-Chara K, Born J, Schultes B. A single night of sleep deprivation increases ghrelin levels and feelings of hunger in normal-weight healthy men. J Sleep Res. 2008; 17: 331-4.

69. Dickson SL, Luckman SM. Induction of c-fos messenger ribonucleic acid in neuropeptide $\mathrm{Y}$ and growth hormone (GH)-releasing factor neurons in the rat arcuate nucleus following systemic injection of the GH secretagogue, GH-releasing peptide-6. Endocrinology. 1997; 138: 771-7.

70. Jerlhag E, Egecioglu E, Landgren S, Salomé N, Heilig M, Moechars $\mathrm{D}$, et al. Requirement of central ghrelin signaling for alcohol reward. Proc Natl Acad Sci. 2009; 106: 11318-23.

71. Ahima RS, Antwi DA. Brain regulation of appetite and satiety. Endocrinol Metab Clin North Am. 2008; 37: 811-23.

72. Dickson SL, Egecioglu E, Landgren S, Skibicka KP, Engel JA, Jerlhag E. The role of the central ghrelin system in reward from food and chemical drugs. Mol Cell Endocrinol. 2011; 340: 80-7.

73. Skibicka KP, Hansson C, Egecioglu E, Dickson SL. Role of ghrelin in food reward: impact of ghrelin on sucrose self-administration and mesolimbic dopamine and acetylcholine receptor gene expression. Addict Biol. 2012; 17: 95-107.

74. Diano S, Farr SA, Benoit SC, McNay EC, da Silva I, Horvath B, et al. Ghrelin controls hippocampal spine synapse density and memory performance. Nat Neurosci. 2006; 9: 381-8.

75. Kanoski SE, Fortin SM, Ricks KM, Grill HJ. Ghrelin signaling in the ventral hippocampus stimulates learned and motivational aspects of feeding via PI3K-Akt signaling. Biol Psychiatry. 2013; 73: 915-23.

76. Andrews ZB, Erion D, Beiler R, Liu ZW, Abizaid A, Zigman J, et al. Ghrelin promotes and protects nigrostriatal dopamine function via a
UCP2-dependent mitochondrial mechanism. J Neurosci. 2009; 29: 14057-65.

77. Moon M, Kim HG, Hwang L, Seo JH, Kim S, Hwang S, et al. Neuroprotective effect of ghrelin in the 1-methyl-4-phenyl-1,2,3,6tetrahydropyridine mouse model of Parkinson's disease by blocking microglial activation. Neurotox Res. 2009; 15: 332-47.

78. Molofsky AV, Krencik R, Krenick R, Ullian EM, Ullian E, Tsai H, et al. Astrocytes and disease: a neurodevelopmental perspective. Genes Dev. 2012; 26: 891-907.

79. Bélanger M, Magistretti PJ. The role of astroglia in neuroprotection Dialogues Clin Neurosci. 2009; 11: 281-95.

80. Fuente-Martin E, Garcia-Caceres C, Morselli E, Clegg DJ, Chowen JA, Finan B, et al. Estrogen, astrocytes and the neuroendocrine control of metabolism. Rev Endocr Metab Disord. 2013; 14: 331-8.

81. García-Cáceres C, Fuente-Martín E, Argente J, Chowen JA. Emerging role of glial cells in the control of body weight. Mol Metab. 2012; 1 $37-46$.

82. Tak PP, Firestein GS. NF-kappaB: a key role in inflammatory diseases. J Clin Invest. 2001; 107: 7-11.

83. Brambilla R, Bracchi-Ricard V, Hu W-H, Frydel B, Bramwell A, Karmally $\mathrm{S}$, et al. Inhibition of astroglial nuclear factor kappaB reduces inflammation and improves functional recovery after spinal cord injury. J Exp Med. 2005; 202: 145-56.

84. Brambilla R, Persaud T, Hu X, Karmally S, Shestopalov VI, Dvoriantchikova G, et al. Transgenic inhibition of astroglial NFkappa B improves functional outcome in experimental autoimmune encephalomyelitis by suppressing chronic central nervous system inflammation. J Immunol Baltim Md 1950. 2009; 182: 2628-40.

85. Brambilla R, Morton PD, Ashbaugh JJ, Karmally S, Lambertsen KL, Bethea JR. Astrocytes play a key role in EAE pathophysiology by orchestrating in the CNS the inflammatory response of resident and peripheral immune cells and by suppressing remyelination. Glia. 2014; 62: 452-67.

86. Fu ES, Zhang YP, Sagen J, Candiotti KA, Morton PD, Liebl DJ, et al. Transgenic inhibition of glial NF-kappa B reduces pain behavior and inflammation after peripheral nerve injury. PAIN. 2010; 148: 509-18.

87. Füchtbauer L, Groth-Rasmussen M, Holm TH, Løbner M, ToftHansen H, Khorooshi R, et al. Angiotensin II Type 1 receptor (AT1) signaling in astrocytes regulates synaptic degeneration-induced leukocyte entry to the central nervous system. Brain Behav Immun. 2011; 25: 897-904.

88. Khorooshi R, Babcock AA, Owens T. NF-кB-driven STAT2 and CCL2 expression in astrocytes in response to brain injury. J Immunol. 2008; 181: 7284-91

89. Dvoriantchikova G, Barakat D, Brambilla R, Agudelo C, Hernandez $\mathrm{E}$, Bethea JR, et al. Inactivation of astroglial NF- $\mathrm{KB}$ promotes survival of retinal neurons following ischemic injury. Eur $\mathrm{J}$ Neurosci. 2009; 30: 175-85.

90. Barakat DJ, Dvoriantchikova G, Ivanov D, Shestopalov VI. Astroglial $\mathrm{NF}-\kappa \mathrm{B}$ mediates oxidative stress by regulation of NADPH oxidase in a model of retinal ischemia reperfusion injury. J Neurochem. 2012; 120: 586-97.

91. Colombo E, Di Dario M, Capitolo E, Chaabane L, Newcombe J, Martino G, et al. Fingolimod may support neuroprotection via blockade of astrocyte nitric oxide. Ann Neurol. 2014; 76: 325-37.

92. Qian Y, Liu C, Hartupee J, Altuntas CZ, Gulen MF, Jane-Wit D, et al. The adaptor Act1 is required for interleukin 17-dependen signaling associated with autoimmune and inflammatory disease. Nat Immunol. 2007; 8: 247-56.

93. Spiegel S, Milstien S. The outs and the ins of sphingosine-1-phosphate in immunity. Nat Rev Immunol. 2011; 11: 403-15. 
94. Fischer I, Alliod C, Martinier N, Newcombe J, Brana C, Pouly S. Sphingosine kinase 1 and sphingosine 1-phosphate receptor 3 are functionally upregulated on astrocytes under pro-inflammatory conditions. PLOS ONE. 2011; 6: e23905. doi: 10.1371/journal. pone. 0023905

95. Choi JW, Gardell SE, Herr DR, Rivera R, Lee CW, Noguchi K, et al. FTY720 (fingolimod) efficacy in an animal model of multiple sclerosis requires astrocyte sphingosine 1-phosphate receptor 1 (S1P1) modulation. Proc Natl Acad Sci. 2011; 108: 751-6.

96. Berger J, Moller DE. The mechanisms of action of PPARs. Annu Rev Med. 2002; 53: 409-35.

97. Ozcan U, Cao Q, Yilmaz E, Lee AH, Iwakoshi NN, Ozdelen E, et al. Endoplasmic reticulum stress links obesity, insulin action, and type 2 diabetes. Science. 2004; 306: 457-61.

98. Huang C, Lin C, Haataja L, Gurlo T, Butler AE, Rizza RA, et al. High expression rates of human islet amyloid polypeptide induce endoplasmic reticulum stress mediated beta-cell apoptosis, a characteristic of humans with type 2 but not type 1 diabetes. Diabetes. 2007; 56: 2016-27.

99. Sachdeva MM, Claiborn KC, Khoo C, Yang J, Groff DN, Mirmira RG, et al. Pdx1 (MODY4) regulates pancreatic beta cell susceptibility to ER stress. Proc Natl Acad Sci USA. 2009; 106: 19090-5.

100. Schneeberger M, Dietrich MO, Sebastián D, Imbernón M, Castaño C, Garcia A, et al. Mitofusin 2 in POMC neurons connects ER stress with leptin resistance and energy imbalance. Cell. 2013; 155: 17287.

101. Contreras C, González-García I, Martínez-Sánchez N, SeoaneCollazo P, Jacas J, Morgan DA, et al. Central ceramide-induced hypothalamic lipotoxicity and ER stress regulate energy balance. Cell Rep. 2014; 9: 366-77.

102. Yang L, Calay ES, Fan J, Arduini A, Kunz RC, Gygi SP, et al. S-Nitrosylation links obesity-associated inflammation to endoplasmic reticulum dysfunction. Science. 2015; 349: 500-6.

103. Ma X, Xu L, Alberobello AT, Gavrilova O, Bagattin A, Skarulis M, et al. Celastrol protects against obesity and metabolic dysfunction through activation of a HSF1-PGC1 $\alpha$ transcriptional axis. Cell Metab. 2015; 22: 695-708.

104. Hosoi T, Sasaki M, Miyahara T, Hashimoto C, Matsuo S, Yoshii M, et al. Endoplasmic reticulum stress induces leptin resistance. Mol Pharmacol. 2008; 74: 1610-9.

105. Ozcan L, Ergin AS, Lu A, Chung J, Sarkar S, Nie D, et al. Endoplasmic reticulum stress plays a central role in development of leptin resistance. Cell Metab. 2009; 9: 35-51.

106. Turpin SM, Nicholls HT, Willmes DM, Mourier A, Brodesser S, Wunderlich CM, et al. Obesity-induced CerS6-dependent C16:0 ceramide production promotes weight gain and glucose intolerance. Cell Metab. 2014; 20: 678-86.

107. Contreras C, González-García I, Seoane-Collazo P, MartínezSánchez N, Liñares-Pose L, Rial-Pensado E, et al. Reduction of hypothalamic endoplasmic reticulum stress activates browning of white fat and ameliorates obesity. Diabetes. 2017; 66: 87-99.

108. Borg ML, Omran SF, Weir J, Meikle PJ, Watt MJ. Consumption of a high-fat diet, but not regular endurance exercise training, regulates hypothalamic lipid accumulation in mice. J Physiol. 2012; 590: 4377-89.

109. Ramírez S, Martins L, Jacas J, Carrasco P, Pozo M, Clotet J, et al. Hypothalamic ceramide levels regulated by CPT1C mediate the orexigenic effect of ghrelin. Diabetes. 2013; 62: 2329-37.

110. Kooijman S, van den Heuvel JK, Rensen PCN. Neuronal control of brown fat activity. Trends Endocrinol Metab TEM. 2015; 26: 65768.

111. López M, Nogueiras R, Tena-Sempere M, Diéguez C. Hypothalamic
AMPK: a canonical regulator of whole-body energy balance. Nat Rev Endocrinol. 2016; 12: 421-32.

112. Tseng YH, Cypess AM, Kahn CR. Cellular bioenergetics as a target for obesity therapy. Nat Rev Drug Discov. 2010; 9: 465-82.

113. Villarroya F, Vidal-Puig A. Beyond the sympathetic tone: the new brown fat activators. Cell Metab. 2013; 17: 638-43.

114. Nedergaard J, Cannon B. The browning of white adipose tissue: some burning issues. Cell Metab. 2014; 20: 396-407.

115. López M, Varela L, Vázquez MJ, Rodríguez-Cuenca S, González CR, Velagapudi VR, et al. Hypothalamic AMPK and fatty acid metabolism mediate thyroid regulation of energy balance. Nat Med. 2010; 16: 1001-8.

116. Martínez de Morentin PB, González-García I, Martins L, Lage R, Fernández-Mallo D, Martínez-Sánchez N, et al. Estradiol regulates brown adipose tissue thermogenesis via hypothalamic AMPK. Cell Metab. 2014; 20: 41-53.

117. Morrison SF, Madden CJ. Central nervous system regulation of brown adipose tissue. Compr Physiol. 2014; 4: 1677-713.

118. Contreras C, Gonzalez F, Fernø J, Diéguez C, Rahmouni K, Nogueiras $\mathrm{R}$, et al. The brain and brown fat. Ann Med. 2015; 47: 150-68.

119. Fisher FM, Kleiner S, Douris N, Fox EC, Mepani RJ, Verdeguer $\mathrm{F}$, et al. FGF21 regulates PGC-1 $\alpha$ and browning of white adipose tissues in adaptive thermogenesis. Genes Dev. 2012; 26: 271-81.

120. Ruan HB, Dietrich MO, Liu ZW, Zimmer MR, Li MD, Singh JP, et al. O-GlcNAc transferase enables AgRP neurons to suppress browning of white fat. Cell. 2014; 159: 306-17.

121. Cohen P, Levy JD, Zhang Y, Frontini A, Kolodin DP, Svensson KJ, et al. Ablation of PRDM16 and beige adipose causes metabolic dysfunction and a subcutaneous to visceral fat switch. Cell. 2014; 156: 304-16.

122. Cakir I, Cyr NE, Perello M, Litvinov BP, Romero A, Stuart RC, et al. Obesity induces hypothalamic endoplasmic reticulum stress and impairs proopiomelanocortin (POMC) post-translational processing. J Biol Chem. 2013; 288: 17675-88.

123. Won JC, Jang PG, Namkoong C, Koh EH, Kim SK, Park JY, et al. Central administration of an endoplasmic reticulum stress inducer inhibits the anorexigenic effects of leptin and insulin. Obes Silver Spring Md. 2009; 17: 1861-5.

124. Mayer CM, Belsham DD. Palmitate attenuates insulin signaling and induces endoplasmic reticulum stress and apoptosis in hypothalamic neurons: rescue of resistance and apoptosis through adenosine 5 , monophosphate-activated protein kinase activation. Endocrinology. 2010; 151: 576-85.

125. Diaz B, Fuentes-Mera L, Tovar A, Montiel T, Massieu L, MartínezRodríguez HG, et al. Saturated lipids decrease mitofusin 2 leading to endoplasmic reticulum stress activation and insulin resistance in hypothalamic cells. Brain Res. 2015; 1627: 80-9.

126. Kleinridders A, Schenten D, Könner AC, Belgardt BF, Mauer J, Okamura $\mathrm{T}$, et al. MyD88 signaling in the CNS is required for development of fatty acid-induced leptin resistance and dietinduced obesity. Cell Metab. 2009; 10: 249-59.

127. Milanski M, Degasperi G, Coope A, Morari J, Denis R, Cintra DE, et al. Saturated fatty acids produce an inflammatory response predominantly through the activation of TLR4 signaling in hypothalamus: implications for the pathogenesis of obesity. J Neurosci Off J Soc Neurosci. 2009; 29: 359-70.

128. Kanczkowski W, Alexaki VI, Tran N, Großklaus S, Zacharowski K, Martinez A, et al. Hypothalamo-pituitary and immune-dependent adrenal regulation during systemic inflammation. Proc Natl Acad Sci. 2013; 110: 14801-6.

129. Hosoi T, Yokoyama S, Matsuo S, Akira S, Ozawa K. Myeloid 
differentiation factor 88 (MyD88)-deficiency increases risk of diabetes in mice. PloS One. 2010; 5: e12537. doi: 10.1371/journal. pone. 0012537

130. Giorgi C, Missiroli S, Patergnani S, Duszynski J, Wieckowski MR, Pinton P. Mitochondria-associated membranes: composition, molecular mechanisms, and physiopathological implications. Antioxid Redox Signal. 2015; 22: 995-1019.

131. van Vliet AR, Verfaillie T, Agostinis P. New functions of mitochondria associated membranes in cellular signaling. Biochim Biophys Acta. 2014; 1843: 2253-62.

132. Zhang X, Wang C, Song G, Gan K, Kong D, Nie Q, et al. Mitofusion2-mediated alleviation of insulin resistance in rats through reduction in lipid intermediate accumulation in skeletal muscle. J Biomed Sci. 2013; 20: 45. doi: 10.1186/1423-0127-20-45.

133. Nie Q, Wang C, Song G, Ma H, Kong D, Zhang X, et al. Mitofusin 2 deficiency leads to oxidative stress that contributes to insulin resistance in rat skeletal muscle cells. Mol Biol Rep. 2014; 41: 6975-83

134. Könner AC, Brüning JC. Selective insulin and leptin resistance in metabolic disorders. Cell Metab. 2012; 16: 144-52.

135. Clegg DJ, Gotoh K, Kemp C, Wortman MD, Benoit SC, Brown LM, et al. Consumption of a high-fat diet induces central insulin resistance independent of adiposity. Physiol Behav. 2011; 103: 106.

136. Prada PO, Zecchin HG, Gasparetti AL, Torsoni MA, Ueno M, Hirata AE, et al. Western diet modulates insulin signaling, c-Jun $\mathrm{N}$-terminal kinase activity, and insulin receptor substrate-1 1 er307 phosphorylation in a tissue-specific fashion. Endocrinology. 2005; 146: $1576-87$.

137. Jais A, Brüning JC. Hypothalamic inflammation in obesity and metabolic disease. J Clin Invest. 2017; 127: 24-32.

138. Thaler JP, Yi CX, Schur EA, Guyenet SJ, Hwang BH, Dietrich MO, et al. Obesity is associated with hypothalamic injury in rodents and humans. J Clin Invest. 2012; 122: 153-62.

139. Morton GJ, Cummings DE, Baskin DG, Barsh GS, Schwartz MW. Central nervous system control of food intake and body weight. Nature. 2006; 443: 289-95.

140. Friedman JM, Halaas JL. Leptin and the regulation of body weight in mammals. Nature. 1998; 395: 763-70.

141. Coll AP, Farooqi IS, O'Rahilly S. The hormonal control of food intake. Cell. 2007; 129: 251-62.

142. Cone RD. Anatomy and regulation of the central melanocortin system. Nat Neurosci. 2005; 8: 571-8.

143. Sandoval D, Cota D, Seeley RJ. The integrative role of CNS fuelsensing mechanisms in energy balance and glucose regulation. Annu Rev Physiol. 2008; 70: 513-35.

144. Marino JS, Xu Y, Hill JW. Central insulin and leptin-mediated autonomic control of glucose homeostasis. Trends Endocrinol Metab TEM. 2011; 22: 275-85.

145. Lam TKT, Schwartz GJ, Rossetti L. Hypothalamic sensing of fatty acids. Nat Neurosci. 2005; 8: 579-84.

146. Friedman JM. Obesity: Causes and control of excess body fat. Nature. 2009; 459: 340-2.
147. Belgardt BF, Brüning JC. CNS leptin and insulin action in the control of energy homeostasis. Ann NY Acad Sci. 2010; 1212: 97-113.

148. Myers MG, Leibel RL, Seeley RJ, Schwartz MW. Obesity and leptin resistance: distinguishing cause from effect. Trends Endocrinol Metab TEM. 2010; 21: 643-51.

149. Elmquist JK, Flier JS. Neuroscience. The fat-brain axis enters a new dimension. Science. 2004; 304: 63-4.

150. Rahmouni K, Correia MLG, Haynes WG, Mark AL. Obesityassociated hypertension: new insights into mechanisms. Hypertens Dallas Tex 1979. 2005; 45: 9-14.

151. Dietrich MO, Horvath TL. Feeding signals and brain circuitry. Eur J Neurosci. 2009; 30: 1688-96.

152. Myers MG, Cowley MA, Münzberg H. Mechanisms of leptin action and leptin resistance. Annu Rev Physiol. 2008;70: 537-56.

153. Cai D. Neuroinflammation and neurodegeneration in overnutritioninduced diseases. Trends Endocrinol Metab TEM. 2013; 24: 40-7.

154. Meng Q, Cai D. Defective hypothalamic autophagy directs the central pathogenesis of obesity via the IkappaB kinase beta (IKKbeta)/NFkappaB pathway. J Biol Chem. 2011; 286: 32324-32.

155. Purkayastha S, Zhang H, Zhang G, Ahmed Z, Wang Y, Cai D. Neural dysregulation of peripheral insulin action and blood pressure by brain endoplasmic reticulum stress. Proc Natl Acad Sci USA. 2011; 108: 2939-44.

156. Purkayastha S, Zhang G, Cai D. Uncoupling the mechanisms of obesity and hypertension by targeting hypothalamic IKK- $\beta$ and NFкB. Nat Med. 2011; 17: 883-7.

157. Zhang G, Li J, Purkayastha S, Tang Y, Zhang H, Yin Y, et al. Hypothalamic programming of systemic ageing involving IKK- $\beta$, NF-kB and GnRH. Nature. 2013; 497: 211-6.

158. Purkayastha S, Cai D. Neuroinflammatory basis of metabolic syndrome. Mol Metab. 2013; 2: 356-63.

159. Li J, Tang Y, Cai D. IKK $\beta / \mathrm{NF}-\kappa \mathrm{B}$ disrupts adult hypothalamic neural stem cells to mediate a neurodegenerative mechanism of dietary obesity and pre-diabetes. Nat Cell Biol. 2012; 14: 999-1012.

160. Li J, Tang Y, Purkayastha S, Yan J, Cai D. Control of obesity and glucose intolerance via building neural stem cells in the hypothalamus. Mol Metab. 2014; 3: 313-24.

161. Tang Y, Cai D. Hypothalamic inflammation and GnRH in aging development. Cell Cycle Georget Tex. 2013; 12: 2711-2.

162. Smith K. Neuroscience: Settling the great glia debate. Nature. 2010; 468: $160-2$.

163. Allen NJ, Barres BA. Neuroscience: Glia - more than just brain glue. Nature. 2009; 457: 675-7.

164. Kohman RA, Rhodes JS. Neurogenesis, inflammation and behavior. Brain Behav Immun. 2013; 27: 22-32.

165. Yan J, Zhang H, Yin Y, Li J, Tang Y, Purkayastha S, et al. Obesityand aging-induced excess of central transforming growth factor- $\beta$ potentiates diabetic development via an RNA stress response. Nat Med. 2014; 20: 1001-8.

166. Valdearcos M, Xu AW, Koliwad SK. Hypothalamic inflammation in the control of metabolic function. Annu Rev Physiol. 2015; 77: 131-60. 